\title{
The Rationale for the Use of Antiretroviral Therapy in COVID-19: Where Hope Meets Skepticism!
}

\author{
Maha S Husain ${ }^{1}$, Sahar Fatima ${ }^{2}$, Iqbal Ratnani ${ }^{3}$ and Salim Surani ${ }^{4 *}$ \\ ${ }^{1}$ Dow International Medical College, Karachi, Pakistan \\ ${ }^{2}$ Houston Methodist Hospital, Houston, Texas, USA \\ ${ }^{3}$ Assistant Professor of Anesthesiology, Houston Methodist Hospital, Houston, Texas, \\ USA \\ ${ }^{4}$ Adjunct Clinical Professor of Medicine, Texas A\&M University, Texas, USA \\ *Corresponding Author: Salim Surani, Adjunct Clinical Professor of Medicine, \\ Texas A\&M University, Texas, USA.
}

Received: March 25, 2020

Published: April 13, 2020

(c) All rights are reserved by Salim Surani., et al.
Affecting nearly 300,000 people around the world and claiming greater than 10,000 lives, the novel coronavirus-related respiratory illness has been declared a global pandemic and a public health emergency by the WHO [1]. The roots of this problem can be traced into early December of 2019, when the Index cases of what were investigated as 'pneumonia of unknown origin' were reported in Wuhan, the epicenter of the disease in China.

Coronavirus belongs to the family Coronaviradae and is an enveloped, positive, single stranded RNA virus, which means that it has the ability to infect humans and animals (camels, cattle, cats and bats). It has 4 subfamilies that include Alphacoronavirus, Betacoronavirus, Gammacoronavirus and Deltacoronavirus. Alphacoronavirus and Betacoronavirus infect humans, whereas Gammacoronavirus and Deltacoronavirus infect animals [2]. Rarely the sub-families can cross-infect. In fact, the first reported human cases are believed to have resulted from animal-human transmission. This has been followed by massively growing numbers mainly attributed to human-human (community) spread [3].

The most dangerous human forms, the Middle East respiratory syndrome coronavirus (MERS-CoV) and the Severe Acute Respiratory Syndrome coronavirus (SARS-CoV) belong to the Betacoronavirus subfamily. Due to the structural similarities between the novel coronavirus and SARS-CoV, this new virus has been named as the SARS-CoV 2.

The deadly coronavirus infection has spread to $163+$ countries worldwide. Within the United States, there are almost 18,000 confirmed cases distributed in all the 50 states [4]. With no definitive and standardized treatment plan and vaccine, exponentially increasing numbers have terrified people across the globe forcing nationwide lockdowns and states of emergency to slow virus progression. There are a number of active clinical trials aiming to devise a treatment plan. Ongoing research has revealed structural similarities between the coronavirus and HIV. Studies have also shown that COVID-19 has HIV like mutations but is 1000 times more potent than HIV. These mutations differentiate COVID-19 from other members of the subfamily and could be the reason as to why the virus is contagious and has a mechanism of infection similar to HIV [5]. The novel coronavirus (COVID-19) has a mutation that creates a cleavage site in the spike protein of the virus. Spike protein is what allows the virus to enter the host cell. The spike protein is initially inactive, but the virus causes the furin gene to activate the spike protein which is then capable of attaching the virus to the host cell. This is how the virus infects $[6,7]$.

The COVID-19 structure has a couple of inserts that are common in HIV, this is the reason as to why people have tried antiretrovirals such as Lopinavir, Darunavir, Ritonavir, which are protease inhibitors for this disease. The job of a protease inhibitor is to inhibit the enzyme protease, which causes HIV to break down into small particles and cause infectivity and viral replication. HIV is just as dangerous as COVID-19 and researchers are continuing to try a variety of antiretrovirals for the COVID-19. Thailand has tried to combine Lopinavir with Ritonavir and a flu drug and has seen that the patient was negative after a few days of taking this drug combination [8]. Japanese government has initiated clinical trials testing Anti-HIV for treatment of COVID-19 [9]. Remdesivir (an adenosine analog-decreases viral RNA production) is another broadspectrum antiviral agent. It was originally developed to treat Ebola virus in 2017. Remdesivir has shown promising results in treating COVID-19 [10]. Currently it is being tested. Since there are no other ways to treat the chaos that surrounds us currently, researchers are trying their best to come up with something that could contain the world current situation.

Amid the COVID-19 crisis, researchers around the globe have been working around the clock to develop a treatment plan to successfully treat patients. In this scenario of confusion and skepticism, the discovery of structural similarities between HIV and COVID-19 is groundbreaking and provides a direction to consolidate the efforts to devise a treatment strategy. In addition, chloroquine, hydroxychloroquine with Zithromax has also shown some positive results [11]. 


\section{Bibliography}

1. World health organization (WHO), Coronavirus disease 2019 (COVID-19) Situation Report-59 (2020).

2. Cascella M., et al. "Features, Evaluation and Treatment Coronavirus (COVID-19)". In: StatPearls [Internet]. Treasure Island (FL): StatPearls Publishing (2020).

3. Centers for Disease Control and Prevention (CDC), Coronavirus disease 2019, Situation Summary - Updated (2020).

4. Business insider (2020).

5. Coronavirus Research News (2020).

6. Ma Y., et al. "ACE2 shedding and furin abundance in target organs may influence the efficiency of SARS-CoV-2 entry" (2020).

7. Pradhan P., et al. "Uncanny similarity of unique inserts in the 2019-nCoV spike protein to HIV-1 gp120 and Gag".

8. Cao B., et al. "A trial of lopinavir-ritonavir in adults hospitalized with severe Covid-19". New England Journal of Medicine (2020).

9. Advisory Board, the daily briefing, Can drugs meant for HIV treat the new coronavirus? (2020).

10. Al-Tawfiq J., et al. "Remdesivir as a possible therapeutic option for the COVID-19". Travel Medicine and Infectious Disease 5 (2020): 101615.

11. Gautret P., et al. "Hydroxychloroquine and azithromycin as a treatment of COVID-19: results of an open-label non-randomized clinical trial". International Journal of Antimicrobial Agents (2020).

\section{Assets from publication with us}

- Prompt Acknowledgement after receiving the article

- Thorough Double blinded peer review

- Rapid Publication

- Issue of Publication Certificate

- High visibility of your Published work

Website: www.actascientific.com/

Submit Article: www.actascientific.com/submission.php

Email us: editor@actascientific.com

Contact us: +919182824667 